\title{
From coral framework to rhodolith bed: sedimentary footprint of the 1982/1983 ENSO in the Galápagos
}

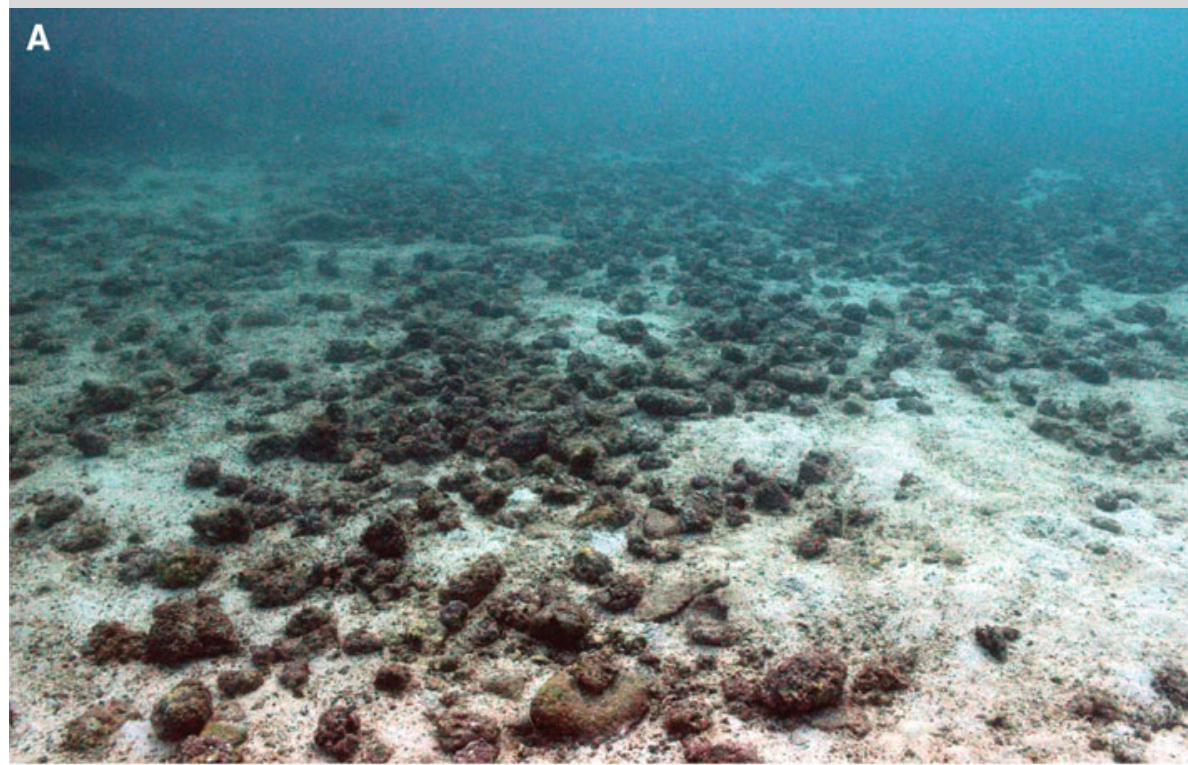

The Galápagos Islands are strongly influenced by ENSO events, and biological impacts of ENSO on the terrestrial and marine fauna are well documented. Coral reefs suffer extensively, and the 1982/1983 and 1997/1998 ENSO events caused widespread coral mortality (Glynn and Ault 2000). Of the two events, that of $1982 / 1983$ had the most impact on Galápagos scleractinian corals (Glynn et al. 2001). At Isla Santa Fe (southern Galápagos archipelago, Ecuador, N0 $48^{\prime} 12.13^{\prime \prime}$,

W90 $02^{\prime} 19.24^{\prime \prime}$ ), incipient coral frameworks, formed primarily by Pocillopora spp., Porites $l o-$ bata and Pavona spp., had existed on rocky substrate to 4-m water depth prior to 1982/1983 (Glynn and Wellington 1983). At this site, virtually total mortality was observed during this event (Glynn 1994), and over the following three decades, only minimal recovery has taken place. Instead, the framework has been entirely eroded and degraded into rubble-sized fragments. By the time of the surveys in 2013, coralline algae had formed crusts with protuberances of up to $6 \mathrm{~mm}$ height, completely coating bioeroded coral clasts. This lead to
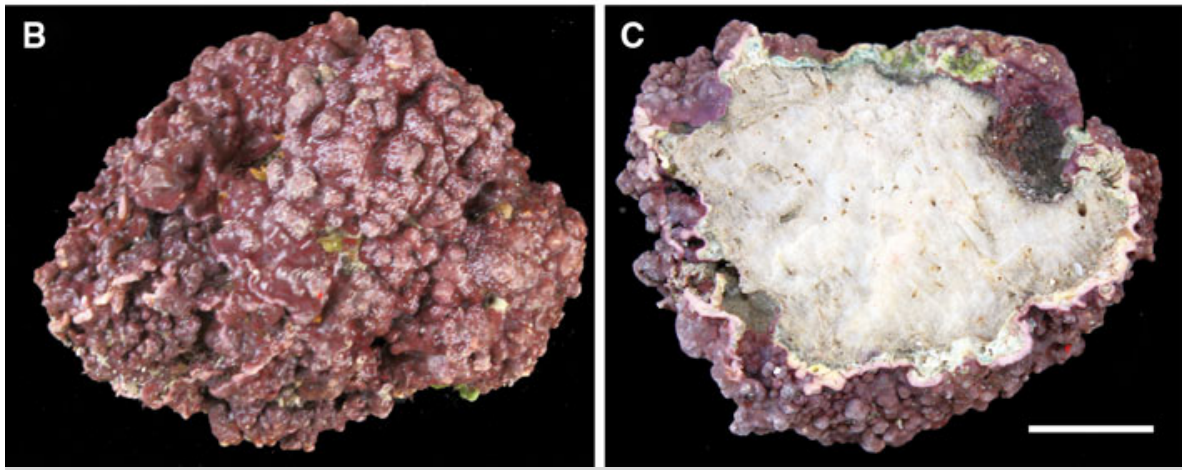
the formation of extensive rhodolith beds on the seafloor surrounding the former coral framework at a distance of up to $30 \mathrm{~m}$ with individual rhodoliths reaching diameters of up to $15 \mathrm{~cm}$ (Fig. 1). While coral biomass has been greatly reduced, and so far not recovered, carbonate mass has been transferred from a coral framework to a rubble bed, which has allowed a great increase in coralline algal biomass due to new substratum availability. Hence, environmentally triggered flattening of coral frameworks has lead to the formation of rhodolith beds within a short time frame emphasizing the high temporal variability in carbonate budgets of shallow marine systems (Perry et al. 2012).

Fig. 1 a Rhodolith bed in close vicinity of pre-ENSO coral framework, b Rhodolith containing nucleus composed of Pavona sp. bioclast (c). Scale bar is $1 \mathrm{~cm}$

\section{References}

Glynn PW (1994) State of coral reefs in the Galápagos Islands: Natural vs anthropogenic impacts. Mar Pollut Bull 29:131-140 Glynn PW, Ault JS (2000) A biogeographic analysis and review of the far eastern Pacific coral reef region. Coral Reefs 19:1-23

Glynn PW, Wellington GM (1983) Corals and coral reefs of the Galápagos Islands. University of California Press, Berkeley and Los Angeles, CA

Glynn PW, Mate JL, Baker AC, Calderon MO (2001) Coral bleaching and mortality in Panamá and Ecuador during the 1997-1998 El Niño-Southern Oscillation event: spatial/temporal patterns and comparisons with the 1982-1983 event. Bull Mar Sci 69:79-109

Perry CT, Edinger EN, Kench PS, Murphy GN, Smithers SG, Steneck RS, Mumby PJ (2012) Estimating rates of biologically driven coral reef framework production and erosion: a new census-based carbonate budget methodology and applications to the reefs of Bonaire. Coral Reefs 31:853-868

J. Halfar $(\bowtie)$

CPS-Department, University of Toronto, 3359 Mississauga Rd. N, Mississauga, ON L5L 1C6, Canada

e-mail: jochen.halfar@utoronto.ca

B. Riegl

National Coral Reef Institute, Nova Southeastern University, 8000 N Ocean Drive, Dania, FL 33004, USA

Received: 3 April 2013/Accepted: 17 June 2013/Published online: 26 June 2013

Coral Reefs (2013) 32: 985

(C) Springer-Verlag Berlin Heidelberg 2013

DOI $10.1007 / \mathrm{s} 00338-013-1058-5$ 